\title{
The effect of oxygen on formation of syngas contaminants during the thermochemical conversion of biomass
}

\author{
Dennis Schuetzle $^{1}$ (i) $\cdot$ Robert Schuetzle $^{2} \cdot$ S. Kent Hoekman ${ }^{3} \cdot$ Barbara Zielinska $^{3}$
}

Received: 1 July 2015 / Accepted: 30 July 2015/Published online: 8 August 2015

(C) The Author(s) 2015. This article is published with open access at Springerlink.com

\begin{abstract}
The effect of oxygen on the formation of syngas contaminants during the thermochemical conversion of carbonaceous feedstocks has been quantified using an integrated biorefinery plant operated at a biomass input of about 4.5 metric tons/day. This plant combines solids steam reforming and gases steam reforming processes for the conversion of biomass to syngas. It was found that the presence of low concentrations of oxygen (in air) during the thermochemical conversion process had a significant effect on the formation of contaminants in the syngas. For example, particulate organic carbon compounds (organic particulate contaminants) increased from 3.3 to $122 \mathrm{mg} / \mathrm{m}^{3}$ when the oxygen input was increased from $225 \mathrm{ppm}$ to 4.1 vol.\% during the thermochemical conversion of wood to syngas. It is proposed that the primary free radical $\left({ }^{*}\right)$ species $\mathrm{H}^{*}, \mathrm{OH}^{*}$, $\mathrm{O}^{*}, \mathrm{CH}_{3}{ }^{*}$ and $\mathrm{OOH}^{*}$, formed from the presence of $\mathrm{O}_{2}$ in this high-temperature process, react with the myriad of organic compounds in the syngas at varying rates, depending upon their structure and reactivity. These processes represent the primary chemical mechanisms for the formation of high molecular weight hydrocarbons, polynuclear aromatic hydrocarbons, oxygenated hydrocarbons and polymeric materials, commonly referred to as organic particulate contaminants. The potential importance of these free-radical oxidation processes was supported by measuring the
\end{abstract}

Dennis Schuetzle

dennis@reii.us

1 Renewable Energy Institute International (REII), 2020 L Street, Sacramento, CA 95811, USA

2 Greyrock Energy, 2020 L Street, Sacramento, CA 95811, USA

3 Division of Atmospheric Sciences, Desert Research Institute (DRI), 2215 Raggio Parkway, Reno, NV 89512, USA concentrations of selected oxygenated hydrocarbons in the syngas over a range of $225 \mathrm{ppm}$ to $4.1 \mathrm{vol} . \%$ of $\mathrm{O}_{2}$ in the thermochemical process. The concentrations of oxygenated polycyclic aromatic hydrocarbons (hydroxy-naphthalene, dihydroxy-naphthalene, dihydro-indene-2-one, and benzopyranone) increased by 732, 244, 83 and 195 times, respectively, when the oxygen concentration was increased from $225 \mathrm{ppm}$ to $2.5 \mathrm{vol} . \%$. These increases were due to the free-radical oxidation of the highly reactive PAHs during the thermochemical processes. The importance of these oxidation processes was further confirmed by studying the decrease of easily oxidized olefins. For example, the concentrations of 1,3-butadiene, acetylene, propene and ethene decreased by 9.3, 5.2, 4.5 and 3.4 times, respectively, when oxygen in the plant was increased from 1.6 to $2.5 \mathrm{vol} . \%$. It is concluded that the formation of organic particulate contaminants during the thermochemical conversion of carbonaceous feedstocks can be minimized by maintaining the concentration of oxygen below 500 ppm.

Keywords Thermochemical conversion - Gasification Solids steam reforming - Gases steam reforming . Integrated biorefinery - Biomass - Wood - Syngas . Particulate-phase contaminants · Gas-phase contaminants . Oxygen - Oxidation processes - Free-radical reactions . Polynuclear aromatic hydrocarbons - Oxygenated polynuclear aromatic hydrocarbons . Oxygenated volatile organic compounds · Olefins · Diesel fuel · Drop-in fuel

\section{Introduction}

For reasons of energy security, diversity, and climate change concerns, there is growing interest in utilizing lignocellulosic materials as feedstocks for fuels and 
chemicals. DOE's Office of the Biomass Program has established a comprehensive Biomass Multi-Year Program Plan, which defines goals and strategies for the use of biomass resources in helping address the US's energy challenges [1].

Various thermochemical, biochemical and physicochemical conversion processes have been developed for the conversion of biomass and other renewable feedstocks to fuels and chemicals. These processes are typically referred to as integrated biorefineries (IBR), in which biomass is converted into fuels and chemicals [2,3]. The potential of these processes is supported by DOE's recent studies demonstrating that up to one billion tons of biomass per year are available in the US for the production of fuels and chemicals $[4,5]$.

Thermochemical conversion (or gasification) is a very versatile process that utilizes varying concentrations of heat, steam and oxygen to convert nearly any solid, liquid or gaseous carbonaceous feedstocks to syngas. This syngas consists primarily of $\mathrm{H}_{2}$ and $\mathrm{CO}$ with minor concentrations of $\mathrm{CO}_{2}$ and $\mathrm{CH}_{4}$. In addition, tars and other syngas contaminants are formed which must be removed before the syngas can be used to produce fuels and chemicals.

Thermochemical conversion technologies have certain advantages and disadvantages over biochemical conversion technologies [6]. The main advantages are that the feedstock for thermochemical conversion can be any type of biomass including agricultural residues, forestry residues, non-fermentable byproducts from biorefineries, byproducts of food industry, byproducts of any bioprocessing facility and even organic municipal wastes; and the product gases can be converted to a variety of fuels (diesels, synthetic gasoline) and chemicals (methanol, ethanol, urea) as substitutes for petroleum-based chemicals. A major disadvantage of thermochemical conversion is the high costs associated with cleaning the product gas from undesirable contaminants.

In contrast, biochemical processes are feedstock selective and the range of products that can be produced from a particular feedstock is limited. Biological routes to fuels using lignocellulosic feedstocks, such as hydrolysis and fermentation to ethanol, involve pre-treatment steps and subsequent biological processes that are optimized for particular biomass types. As a result, many of these routes have a limited ability to accept mixed or variable feedstocks such as wastes.

There are a multitude of thermochemical conversion process designs which can be classified in terms of the direction of the biomass flow and the method of heating [7]. These processes typically utilize indirect, direct and hybrid reactor designs as follows:
1. Indirect The carbonaceous materials are input into relatively large vessels that are heated externally in the absence of oxygen or air. Steam is typically added to facilitate the conversion of the carbonaceous materials into syngas. These processes are typically operated at less than $1800 \mathrm{~F}\left(982^{\circ} \mathrm{C}\right)$ and with relatively long residence times.

2. Direct This process requires the addition of an oxidant (oxygen or air) with the biomass in order to internally generate the required thermal energy for efficient conversion to syngas.

3. Hybrid Several commercial systems perform the primary thermochemical conversion using indirect heat and a relatively small amount of an oxidant (oxygen or air). The solid carbon residues are then passed to a second vessel in which they are partially oxidized to increase the production of syngas.

All of these thermochemical conversion processes produce various levels of gas-phase and particulate-phase syngas contaminants [8-10], depending upon their design and operating conditions. These particulate-phase contaminants are commonly referred to as organic particulate contaminants, which consist primarily of polynuclear aromatic compounds, high molecular weight hydrocarbons, oxygenated hydrocarbons and polymeric materials. Previous studies have demonstrated that the composition and quantity of these organic particulate contaminants are influenced by thermochemical system operating conditions. For example, it has been found that organic particulate contaminants are reduced by about a factor of five by increasing thermochemical operating temperatures from 750 to $950{ }^{\circ} \mathrm{C}$ [11]. However, no studies have been reported to date that quantify the effect of oxygen on the concentrations of organic particulate contaminants in syngas during thermochemical conversion processes. Therefore, the primary objective of this study was to determine the effect of oxygen on the formation of gas-phase and particulate-phase contaminants during the thermochemical conversion of wood to syngas.

These organic particulate contaminants can have significant adverse effects on downstream catalysts that are used in processes that convert syngas to fuels [12]. Therefore, rigorous syngas quality specifications have been established by several organizations to help insure long catalyst life. For example, the syngas quality specifications established by Greyrock Energy for the production of 'drop-in' diesel fuel are summarized in Table 1 [13]. In addition, several groups have established $\sim 5 \mathrm{mg} / \mathrm{m}^{3}$ limits for organic particulate contaminants (tars) in syngas used in direct-fired, industrial gas turbines, and $10-50 \mathrm{mg} / \mathrm{m}^{3}$ for syngas used in spark ignition and diesel engines [8]. 
Table 1 Maximum recommended contaminant levels for the catalytic conversion of syngas to "dropin" diesel fuel [11]

\begin{tabular}{ll}
\hline Catalyst contaminants & Maximum recommended contaminant levels \\
\hline Hydrogen sulfide $\left(\mathrm{H}_{2} \mathrm{~S}\right)$ and carbonyl sulfide $(\mathrm{COS})$ & $<20 \mathrm{ppb}$ \\
Sulfur dioxide $\left(\mathrm{SO}_{2}\right)$ & $<20 \mathrm{ppb}$ \\
Oxygen $\left(\mathrm{O}_{2}\right)$ & $<500 \mathrm{ppm}$ \\
Ammonia $\left(\mathrm{NH}_{3}\right)$ & $<75 \mathrm{ppb}$ \\
Hydrogen chloride $(\mathrm{HCl})$ & $<35 \mathrm{ppb}$ \\
Nitric acid $\left(\mathrm{HNO}_{3}\right)$ & $<50 \mathrm{ppb}$ \\
Total organic and inorganic particulate matter $(\mathrm{PM})$ & $<500 \mu \mathrm{g} / \mathrm{m}^{3}$ \\
\hline
\end{tabular}

\section{Objectives}

The thermochemical process developed, deployed and tested in this study utilizes indirect heating (Fig. 1). This process was selected since preliminary studies carried out by our group during 2005-2007 [14] demonstrated that this approach had the greatest potential of:

1. Significantly reducing the production of gas-phase and particulate-phase contaminants in the syngas, resulting in reduced capital, operating and maintenance costs required for syngas purification.

2. Maximizing the concentrations of $\mathrm{CO}$ and $\mathrm{H}_{2}$ and minimizing the concentrations of $\mathrm{CH}_{4}$ and $\mathrm{CO}_{2}$ in the syngas, resulting in an increased production of fuels and chemicals.

3. Directly producing $\mathrm{H}_{2}$ and $\mathrm{CO}$ with $\mathrm{H}_{2} / \mathrm{CO}$ ratios in the optimum 2.00-2.30 range required for the production of fuels and chemicals, which eliminates the need for additional unit process such as reverse water gasshift reactors, hydrogen generators, pressure swing absorption systems, etc.
4. Producing high-purity syngas in which oxygen and other gas-phase and particulate-phase contaminants are at very low levels so that the catalysts used for the direct production of liquid fuels will not be adversely affected.

Therefore, the work described in this paper focused on quantifying the potential effect of oxygen on the production of gas-phase and particulate-phase contaminants and on the concentration of $\mathrm{H}_{2}$ and $\mathrm{CO}$ in the syngas.

\section{Experimental}

A pilot-scale integrated biorefinery (Fig. 1) was employed for this investigation. Figure 1 illustrates the primary unit operations used for the conversion of biomass to fuels. The thermochemical conversion (TCC) process includes unit operations \#1-\#4 in which the biomass is converted to purified syngas. The production of "drop-in" fuels from the syngas includes unit operations \#5-\#8. This paper is focused on the potential effect of $\mathrm{O}_{2}$ on the production of
Fig. 1 Process flow diagram for the pilot plant

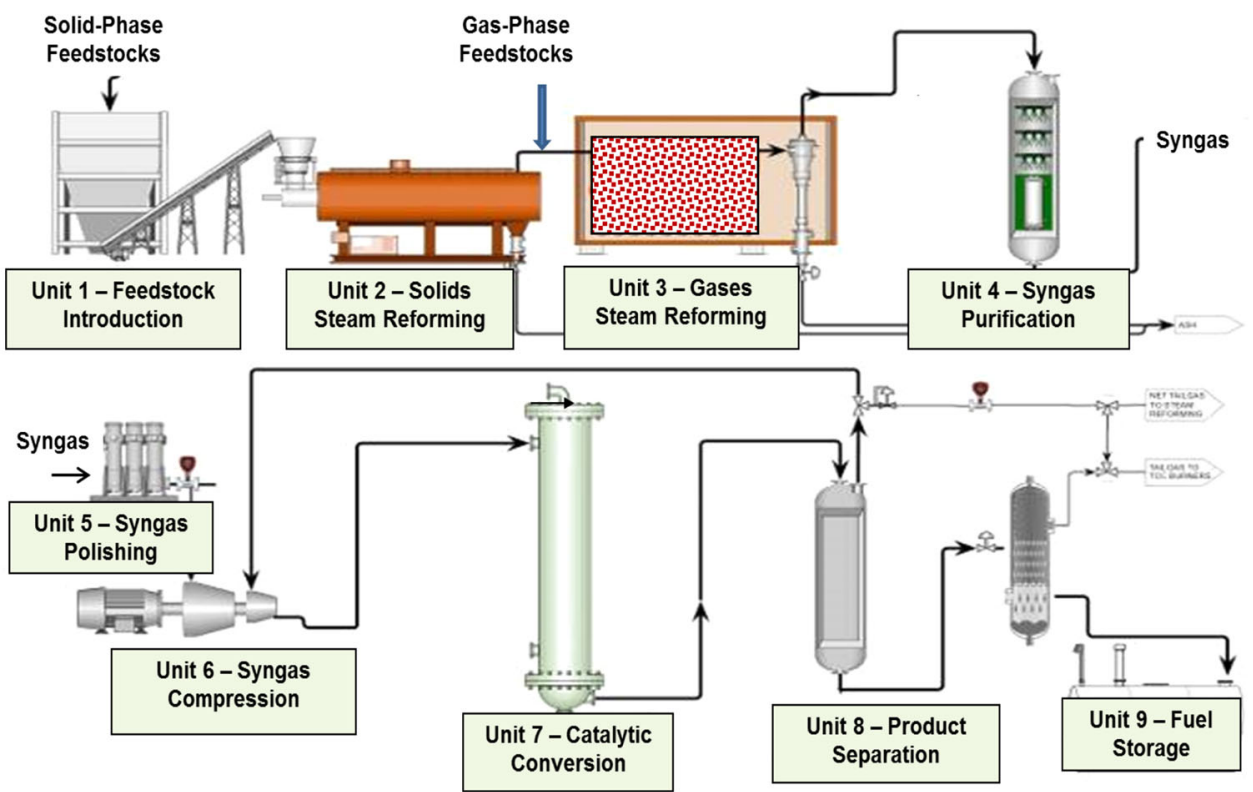


organic particulate contaminants in unit operations \#1-\#4. This integrated biorefinery was operated at about 4.5 metric tons/day biomass input.

\section{Integrated biorefinery}

The pilot integrated biorefinery (Fig. 1) utilizes a two-step steam reforming process that employs heat, pressure and steam in the absence of $\mathrm{O}_{2}$, coupled with a gas purification system, to produce a clean syngas, intended for subsequent catalytic conversion to high-quality, synthetic diesel fuel [13]. The TCC process comprised four primary unit operations: \#1-feedstock introduction, \#2-solids steam reforming, \#3-gases steam reforming, and \#4—syngas purification.

In unit operation \#1, the feedstock is flushed with carbon dioxide to remove any entrained air before it is fed into the solids steam reforming unit operation \#2. An oxygen sensor is used to monitor any remaining oxygen, which was found to average $225 \pm 30 \mathrm{ppm}$ during the several days of plant operation.

Unit operation \#2 utilizes a specifically designed retort chamber that operates in the $1400-1550 \mathrm{~F}\left(760-843{ }^{\circ} \mathrm{C}\right)$ range. The retort is a long cylinder with a series of internal spiral flights. The retort was manufactured from a wrought alloy, RA-330, that is suitable for the temperature range (i.e., $1700 \mathrm{~F}\left(927^{\circ} \mathrm{C}\right)$ maximum) and not reactive with the pyrolysis compounds. The outer casing was designed to withstand 345 kilopascals $(50 \mathrm{psig})$ internal pressure. The vessel and dished ends were constructed of mild steel plates per American Society of Mechanical Engineers (ASME) boiler pressure vessel codes. Ceramic fiber modules, $25 \mathrm{~cm}$ thick and 10 in. thick with a density of $160 \mathrm{~kg} /$ $\mathrm{m}^{3}$, were provided and stud welded to the furnace sidewalls, roof, and discharge end wall. The retort rotates around its longitudinal axis such that the spiral flights convey the feedstock from end to end in a defined period of time. Various devices (e.g., bars and rakes) are used between the flights to cause the feedstock to tumble and improve the rate of heat transfer.

The heating system consists of 36 single-ended radiant (SER) tubes and burners arranged along the sides of the retort that is divided into three equal and independent zones of temperature control. Zone control is implemented in the process control programmable logic controller (PLC). Infrared temperature sensors are provided in each zone to monitor and record the retort temperature profile.

Natural gas is used to fire the SER burners during startup operations, but once steady-state conditions have been achieved, tailgas (a methane-enriched syngas) from the liquid fuels production process may be substituted.

Ash is removed at the end of the retort with an integrated water-cooled auger system. The ash is depressurized to ambient conditions through a valve-lock/hopper system. The solid particles are composed primarily of unconverted carbon, silica, metal oxides, and trace minerals. The ash has commercial applications including as a soil enhancer and in ceramics manufacturing.

A pressure transmitter is provided to monitor and record the pressure inside the solids steam reforming chamber. Control of this pressure is affected by downstream equipment. For example, the chamber pressure will rise if the discharge flow is reduced. Likewise, the pressure will decline if the discharge flow is drawn away faster than the feedstock is supplied. A pressure relief device is provided in the event of a high-pressure control malfunction in downstream equipment.

Unit operation \#2 is a slow pyrolysis process that utilizes a purge gas (steam or carbon dioxide) to convert the solid-phase carbon to gas-phase carbon species in the absence of oxygen $\left(\mathrm{O}_{2}<500 \mathrm{ppm}\right)$. The residence time of the feedstock can be varied from about 5-20 min by changing the rotation speed of the retort.

During this solids steam reforming process, it was found that the carbon in the feedstock was efficiently converted to gas-phase organics and syngas using a steam to feedstock carbon mass ratio of about 1.4/1.0. This ratio is controlled to maximize the conversion of solid-phase carbonaceous compounds into gas-phase carbonaceous products. The average feedstock carbon to syngas carbon conversion efficiency for wood was found to average 85 weight $\%$ under the operating conditions [13] summarized below.

Unit operation \#3 was designed to steam reform the gasphase products, generated from unit operation \#2, into syngas. This unit operates at a tube temperature of $1790-1815 \mathrm{~F}\left(977-991{ }^{\circ} \mathrm{C}\right)$, at a pressure of up to 345 kilopascals $(50 \mathrm{psig})$ and with gas residence times of 3-8 s. The steam injected into unit operation \#3 is superheated with the exhaust from the solids steam reforming chamber burners. The heat exchanger is constructed from an iron/nickel/chromium-based alloy selected for its hightemperature tensile strength, longevity and low maintenance. The steam-to-carbon mass ratio is maintained at about 1.4/1.0. The gas-phase products from the solids steam reforming process and superheated steam (unit operation \#2) are injected into unit \#3 for conversion of the gas-phase organic species into syngas. The resulting syngas is composed primarily of hydrogen $\left(\mathrm{H}_{2}\right)$ and $\mathrm{CO}$, along with lower concentrations of methane $\left(\mathrm{CH}_{4}\right)$ and $\mathrm{CO}_{2}$.

As shown in Fig. 2, unit operation \#4 utilizes several processes to purify the syngas from unit operation \#3 including the following: (\#4-1) a cyclone to remove particles greater than about $3 \mu \mathrm{m}$ in size; (\#4-2); a quench column to collect organic particulate contaminants; (\#4-3) a high-efficiency venturi water scrubber that cools the syngas and then removes organic particulate contaminants 


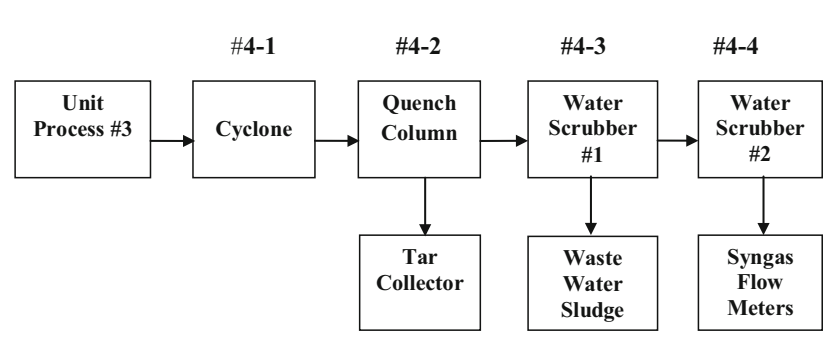

Fig. 2 Syngas purification sub-unit operations

and other fine particulates; (\#4-4) a packed-bed scrubber tower and chemical scavengers to remove sulfur compounds (e.g., $\mathrm{H}_{2} \mathrm{~S}$ ), ammonia, and oxygenated hydrocarbons. The organic particulate contaminants generated from the IBR plant are classified into two types:

1. Type A Organic particulate contaminants Aromatic compounds with 2-3 rings such as naphthalene and anthracene; oxy-arenes such as dihydroxy-benzene; and non-volatile hydrocarbons and oxygenated hydrocarbons such as hydroxy-undecane.

2. Type B Organic particulate contaminants Polynuclear aromatic hydrocarbons (PAH) with four or more rings (non-volatile organic particulate contaminants) such as pyrene and benzo (a) pyrene; oxy-PAHs such as hydroxy-naphthalene; and polymeric materials.

The oxygenated, volatile organic compounds, such as guaiacol and phenol, are removed easily in the water scrubber. Although the gas-phase aromatics, benzene and toluene, are not removed in the scrubber, it has been demonstrated that they pass through the catalyst bed unreacted without any adverse effect on the fuel production catalyst. Therefore, these volatile organics were not classified as organic particulate contaminants, even though they are typically included in the definition of "tars".

The cyclones (Fig. 2, \#4-1) are installed inside the reforming chamber (unit operation \#3) and operate at the elevated temperature of the chamber. This location limits the potential for condensation of unconverted higher molecular weight gaseous components inside the cyclones which would cause fouling and plugging problems and also preserves the thermal energy in the syngas for heat recovery opportunities. Ash is collected from the cyclones and cooled via a water-jacketed auger and valve-lock system.

Following the cyclones, the hot syngas is routed through a quench venturi scrubber system to cool and scrub any remaining particulates, condensable organic particulate contaminants, gases, and other contaminants. First, hot syngas from the cyclones is passed through a series of water-spray quench vessels, which cool the syngas and coagulate and remove the bulk of micro-particles and contaminants. The cooled syngas then passes through a venturi scrubber to remove particles down to $0.5-1 \mu \mathrm{m}$ in size. The syngas is next routed through an optional air cooler and then into a vertical packed-bed tower scrubber system.

The first quench spool is constructed of Hastelloy ${ }^{\mathrm{TM}}$ to handle the high-temperature incoming syngas. All following vessels, lines, the venturi, and packed bed are constructed of 316 stainless steel.

The vertical packed scrubber tower is used to scrub the syngas of sulfur species (such as $\mathrm{SO}_{2}, \mathrm{H}_{2} \mathrm{~S}$ ) using solutions of sodium hydroxide and hydrogen peroxide. The scrubber water $\mathrm{pH}$ is maintained at $9-10$ to maximize scrubber efficiency [13]. Particulate matter is removed from the scrubbing water after passing through a press filter and chiller.

The plant was run at a constant feed rate of about 4.5 metric tons/day using wood chips. The composition of these chips is summarized in the next section. Once it was demonstrated that the plant was operating under stable, steady-state conditions, the following operating data were collected:

1. Biomass feed rate (metric tons $/ \mathrm{h}$ )

2. Temperatures at various locations in the thermochemical system

3. Steam-to-biomass feed ratios

4. Volume of syngas produced per minute (cubic meters/ $\min )$.

\section{Experimental}

\section{Biomass feedstock}

The wood chips used in this study ranged from 0.15 to 2.5 in. $(0.40-6.4 \mathrm{~cm})$ in size. They were sourced from the Michigan and Ohio area and consisted of about $85 \%$ hardwoods and $15 \%$ softwoods. Wood chips, less than about $0.40 \mathrm{~cm}$., were removed by screen segregation. Table 2 summarizes the elemental composition of the wood chips. This concentration of elemental species is typical of that for Midwest hardwood samples.

The moisture content of the feedstocks was used to determine how much steam should be fed into the pilot plant as well as for determining the feedstock carbon conversion efficiency to fuel. Feedstock moisture analysis was carried out using a drying oven following ASTM method \#D442. The moisture content of the wood chips averaged 14.0 weight $\%$ during these tests.

Table 2 also summarizes the average volatile organic carbon and fixed (elemental) carbon constituents in the total feedstock carbon content. It was determined that 86.2 and 13.8 weight $\%$ of the $50.0 \%$ of carbon in the wood 
Table 2 Chemical composition and energy content of the wood feedstock

\begin{tabular}{lc}
\hline Chemical species & Wt.\% (dry basis) \\
\hline Carbon & 50.0 \\
Hydrogen & 5.97 \\
Oxygen & 42.3 \\
Nitrogen & 0.23 \\
Sulfur & 0.01 \\
Chlorine & 0.001 \\
Calcium & 0.20 \\
Potassium & 0.11 \\
Aluminum & 0.003 \\
Magnesium & 0.02 \\
Iron & 0.007 \\
Sodium & 0.02 \\
\hline Carbon analysis & Wt. $\%$ (dry basis) \\
\hline Volatile organic carbon & 86.2 \\
Fixed carbon (elemental) & 13.8 \\
\hline Energy content & MJ/kg (dry basis) \\
\hline Lower heating value (LHV) & 17.57 \\
Higher heating value (HHV) & 20.48 \\
\hline
\end{tabular}

feedstock was volatile organic carbon and fixed (elemental) carbon, respectively.

\section{Oxygen input}

Various levels of air were input to the pilot plant to increase the $\mathrm{O}_{2}$ concentration in five increments from $225 \mathrm{ppm}$ to 4.1 vol.\% to determine the effect of $\mathrm{O}_{2}$ on the concentration of gas-phase and particulate-phase contaminants in the syngas. The concentration of $\mathrm{N}_{2}$ in the syngas was used to estimate the average concentration of $\mathrm{O}_{2}$ that was input into the process, as air. $\mathrm{O}_{2}$ concentrations were also measured in real-time using a Teledyne Model 3190 Oxygen Analyzer. The accuracy of these measurements was about $\pm 5 \%$. We define an $\mathrm{O}_{2}$-free environment when the $\mathrm{O}_{2}$ is less than about 500 ppm.

\section{Real-time syngas analysis}

The concentrations of the major syngas constituents were monitored using a gas analysis system permanently installed at the pilot plant. Integrated syngas samples were collected in Tedlar bags and the major constituents $\left(\mathrm{H}_{2}\right.$, $\mathrm{CO}, \mathrm{CO}_{2}, \mathrm{CH}_{4}$ and $\mathrm{N}_{2}$ ) were determined using gas chromatography (GC). On-line measurements of $\mathrm{H}_{2}, \mathrm{CO}, \mathrm{CO}_{2}$ and $\mathrm{CH}_{4}$ were also made using a Siemens Maxum Edition II Process GC. Syngas samples were also collected and
Table 3 Measured syngas composition and calculated $\mathrm{O}_{2}$ input from the pilot IBR plant utilizing wood feedstock

\begin{tabular}{lcccccc}
\hline Oxygen input & \multicolumn{7}{c}{ Syngas composition (vol.\%) $)^{\mathrm{a}}$} \\
\cline { 2 - 7 } & $\mathrm{N}_{2}$ & $\mathrm{H}_{2}$ & $\mathrm{CO}$ & $\mathrm{CH}_{4}$ & $\mathrm{CO}_{2}$ & $\mathrm{H}_{2} / \mathrm{CO}$ \\
\hline $225 \mathrm{ppm}$ & $<0.20$ & 49 & 23 & 12 & 17 & 2.1 \\
1.0 vol.\% & 3.7 & 44 & 22 & 13 & 16 & 2.0 \\
1.6 vol.\% & 5.9 & 44 & 22 & 13 & 16 & 2.0 \\
2.5 vol.\% & 9.2 & 43 & 19 & 11 & 20 & 2.3 \\
4.1 vol.\% & 15.3 & 37 & 17 & 9 & 23 & 2.2 \\
\hline
\end{tabular}

${ }^{a}$ Measurement accuracy for syngas constituents: $\pm 5 \%$

selected for comprehensive analysis during the test period. Table 3 summarizes the average levels of $\mathrm{N}_{2}, \mathrm{H}_{2}, \mathrm{CO}, \mathrm{CH}_{4}$ and $\mathrm{CO}_{2}$ ( $\pm 5 \%$ accuracy) measured in the dry syngas for the five sampling periods.

The volume $\%$ of $\mathrm{N}_{2}$ measured in the syngas was used to estimate the volume\% of $\mathrm{O}_{2}$ input into the system as follows:

Input $\left[\mathrm{O}_{2}\right]=\left[\mathrm{N}_{2}\right] / 3.73$

Since the pressure in the plant was kept constant throughout the process and since the syngas replaced the steam in the thermochemical process, the concentration of $\mathrm{N}_{2}$ in the syngas was found to be approximately proportional to the concentration of $\mathrm{O}_{2}$ input in the thermochemical conversion system.

\section{Integrated syngas sampling}

Syngas samples were collected once the plant was operating at stable, steady-state conditions. All syngas samples were collected before the final syngas cleanup (purification step). A dilution sampling and analysis approach recently developed and validated by DRI and REII was used to characterize trace contaminants in the syngas produced from thermochemical conversion of wood from the plant $[15$, 16]. This dynamic dilution sampling system was employed to minimize the potential loss of polar organic and particulate species during the sampling of the hot syngas. The hot syngas samples were collected after the cyclones and before the quench column (Fig. 2). Sample collection media included a combination of filters, adsorbent cartridges and evacuated canisters. Results were generated for up to 165 syngas contaminants generated from the conversion of the wood chip feedstocks over the test period.

\section{Characterization of integrated samples}

Special emphasis was placed on the characterization of trace sulfur compounds $\left(\mathrm{H}_{2} \mathrm{~S}\right.$ and $\left.\mathrm{SO}_{2}\right)$; nitrogen compounds $\left(\mathrm{NH}_{3}, \mathrm{HNO}_{3}\right.$ and $\left.\mathrm{NO}_{2}\right)$; chloride compounds $(\mathrm{HCl}$ 
Table 4 Effect of oxygen on the concentration of particulate components in syngas generated from the thermochemical conversion of wood

\begin{tabular}{llll}
\hline Oxygen input & \multicolumn{2}{l}{ Syngas contaminants $\left(\mathrm{mg} / \mathrm{m}^{3}\right)^{\mathrm{a}}$} & \\
\cline { 2 - 4 } & Particulate organic carbon & Particulate elemental carbon & Total carbon containing particulates \\
\hline $225 \mathrm{ppm}$ & 3.3 & 0.6 & 3.9 \\
$1.0 \mathrm{vol} \%$ & 6.4 & 4.1 & 6.5 \\
$1.6 \mathrm{vol} \%$ & 57 & 10 & 269 \\
$2.5 \mathrm{vol} \%$ & 194 & 75 & 220 \\
$4.1 \mathrm{vol} \%$ & 122 & 98 & 67 \\
\hline
\end{tabular}

${ }^{a}$ Measurement accuracy for particulate organic carbon and particulate elemental carbon: $\pm 10 \%$ above $2 \mathrm{mg} / \mathrm{m}^{3}$ and $\pm 15 \%$ between 0.05 and $0.50 \mathrm{mg} / \mathrm{m}^{3}$

and inorganic chlorides); organic particulate contaminants (organic particulates); and inorganic particulate matter (elemental species) since these materials are known contaminants that can adversely affect catalysts used for conversion of syngas to fuels. Trace gas and particulate-phase organic and inorganic chemical species were collected from the syngas stream and characterized using the following procedures as described previously [14-16].

- Thermal optical analysis of total organic C (organic particulate contaminants) and total elemental $\mathrm{C}$ on quartz filters

- GC/MS analysis of $\mathrm{C}_{1}-\mathrm{C}_{11}$ gas-phase volatile organic compounds (VOCs) and chlorinated VOCs $(>50)$ in Summa stainless steel sampling canisters

- Ion chromatography (IC) of chlorides, nitrates and sulfates on quartz filters

- IC analysis of $\mathrm{HCl}, \mathrm{HNO}_{3}$ and $\mathrm{SO}_{2}$ on $\mathrm{K}_{2} \mathrm{CO}_{3}$ impregnated cellulose filters

- GC/TCD and GC/FID analysis of major syngas constituents (6 species)

- GC/MS analysis of higher MW VOCs $\left(\mathrm{C}_{8}-\mathrm{C}_{20}\right)(>25$ species) collected on Tenax cartridges

- HPLC analysis of DNPH derivatives of $\mathrm{C}_{1}-\mathrm{C}_{7}$ carbonyl compounds (14 species)

- Colorimetric analysis of ammonia from citric acid impregnated cellulose filters

- X-ray fluorescence (XRF) analysis of $\mathrm{AgNO}_{3}$-impregnated filters for measurement of $\mathrm{H}_{2} \mathrm{~S}$ (as $\mathrm{AgS}$ )

- XRF analysis of teflon filters for measurement of elemental constituents (51 species)

Gas samples were collected using Tedlar bags and electro-polished stainless steel canisters. Gas chromatography using thermal conductivity, sulfur-selective and nitrogen-selective detectors were used to measure $\mathrm{O}_{2}, \mathrm{~N}_{2}$ and sulfur species in the syngas samples.

In this study, organic particulate contaminants are defined as the concentration of total organic carbon in the particulates collected on quartz filters at room temperature. The concentrations of specific organic particulate contaminants were determined from GC/MS analysis of $\mathrm{C}_{8}-\mathrm{C}_{20}$ hydrocarbons collected from the Tenax cartridges and quartz filters. The possibility of break-through of gasphase species during the Tenax sampling was assessed. It was found that the break-through was not a problem since the concentrations of gas-phase species were low.

\section{Results}

Table 3 summarizes the concentrations of the primary syngas constituents. The concentrations of $\mathrm{H}_{2}$ and $\mathrm{CO}$ decreased as the concentration of $\mathrm{O}_{2}$ increased while the ratio of $\mathrm{H}_{2} / \mathrm{CO}$ remained relatively constant $(2.15 \pm 0.15)$. In contrast, the concentrations of $\mathrm{CO}_{2}$ increased at oxygen inputs of 2.5 and $4.1 \%$.

Table 4 shows that the concentration of particulate organic carbon increased considerably from 3.3 to $122 \mathrm{mg} /$ $\mathrm{m}^{3}$ when $\mathrm{O}_{2}$ in the system was increased from $225 \mathrm{ppm}$ to $4.1 \%$ during the thermochemical conversion process (the accuracy of these measurements are $\pm 15 \%$ between 0.06 and $0.50 \mathrm{mg} / \mathrm{m}^{3}$ and $\pm 10 \%$ above $2 \mathrm{mg} / \mathrm{m}^{3}$ ). This is not surprising since it is well known that organic compounds react readily with $\mathrm{O}_{2}$ under high-temperature conditions to form oxygenated hydrocarbons and polymeric materials that have much lower vapor pressures than their respective hydrocarbon reactants [17-26]. Particulate elemental carbon also increased significantly from 0.6 to $98 \mathrm{mg} / \mathrm{m}^{3}$ as $\mathrm{O}_{2}$ was increased from $225 \mathrm{ppm}$ to $4.1 \%$.

Table 5 summarizes the effect of $\mathrm{O}_{2}$ concentration on particulate sulfates, nitrates, $\mathrm{SO}_{2}$ and $\mathrm{HNO}_{3}$ in the syngas. The concentrations of particulate sulfates were low $\left(1.4 \mu \mathrm{g} / \mathrm{m}^{3}\right)$ when the $\mathrm{O}_{2}$ concentration was $225 \mathrm{ppm}$ but increased to $201 \mu \mathrm{g} / \mathrm{m}^{3}$ when $\mathrm{O}_{2}$ increased to $4.1 \%$. The concentration of $\mathrm{SO}_{2}$ also increased from 1.8 to $240 \mu \mathrm{g} / \mathrm{m}^{3}$ over this range of $\mathrm{O}_{2}$ concentrations. These increases were probably due to the oxidation of reduced sulfur species (e.g., $\mathrm{H}_{2} \mathrm{~S}, \mathrm{COS}$, mercaptans and thiols) to gas-phase $\mathrm{SO}_{2}$, particulate-phase $\mathrm{H}_{2} \mathrm{SO}_{4}$ and inorganic sulfates during the thermochemical process. 
Table 5 The effect of oxygen input on concentrations of particulate and gas-phase sulfur and nitrogen components in syngas generated from the thermochemical conversion of wood

\begin{tabular}{|c|c|c|c|c|c|c|}
\hline \multirow{2}{*}{$\begin{array}{l}\text { Oxygen } \\
\text { input }\end{array}$} & \multicolumn{6}{|l|}{ Syngas contaminants } \\
\hline & $\begin{array}{l}\text { Particulate sulfates } \\
\left(\mu \mathrm{g} / \mathrm{m}^{3}\right)\end{array}$ & $\begin{array}{l}\text { Gas-phase } \mathrm{SO}_{2} \\
\left(\mu \mathrm{g} / \mathrm{m}^{3}\right)\end{array}$ & $\begin{array}{l}\text { Ratio sulfates/ } \\
\mathrm{SO}_{2}\end{array}$ & $\begin{array}{l}\text { Particulate nitrates } \\
\left(\mu \mathrm{g} / \mathrm{m}^{3}\right)\end{array}$ & $\begin{array}{l}\text { Gas-phase } \mathrm{HNO}_{3} \\
\left(\mu \mathrm{g} / \mathrm{m}^{3}\right)\end{array}$ & $\begin{array}{l}\text { Ratio nitrates/ } \\
\mathrm{HNO}_{3}\end{array}$ \\
\hline 225 ppm & 1.4 & 1.8 & 0.8 & 2.2 & 1.3 & 1.7 \\
\hline 1.0 vol. $\%$ & 5.6 & 3.8 & 1.5 & 1.4 & 2.9 & 0.48 \\
\hline 1.6 vol. $\%$ & 8.1 & 13 & 0.6 & 2.3 & 11.4 & 0.20 \\
\hline 2.5 vol. $\%$ & 201 & 240 & 0.8 & 4.8 & 18.6 & 0.26 \\
\hline
\end{tabular}

Table 6 Effect of oxygen input on concentrations of aromatic compounds in syngas generated from the thermochemical conversion of wood

\begin{tabular}{llllllll}
\hline $\begin{array}{l}\text { Oxygen } \\
\text { input }\end{array}$ & \multicolumn{2}{l}{ Syngas contaminants } \\
\cline { 2 - 8 } & $\begin{array}{l}\text { Benzene } \\
(\mathrm{ppm})\end{array}$ & $\begin{array}{l}\text { Toluene } \\
(\mathrm{ppm})\end{array}$ & $\begin{array}{l}\text { Xylenes } \\
(\mathrm{ppm})\end{array}$ & $\begin{array}{l}\text { Naphthalene } \\
\left(\mathrm{mg} / \mathrm{m}^{3}\right)\end{array}$ & $\begin{array}{l}\text { Methyl naphthalene } \\
\left(\mathrm{mg} / \mathrm{m}^{3}\right)\end{array}$ & $\begin{array}{l}\text { Fluorene } \\
\left(\mathrm{mg} / \mathrm{m}^{3}\right)\end{array}$ & $\begin{array}{l}\text { Acenapthene } \\
\left(\mathrm{mg} / \mathrm{m}^{3}\right)\end{array}$ \\
\hline $225 \mathrm{ppm}$ & 5845 & 3.9 & 0.0 & 1.8 & 0.0 & 0.0 & 0.0 \\
$1.0 \mathrm{vol} \%$ & 960 & 25 & 0.21 & 5.4 & 0.014 & 0.004 & 0.075 \\
$1.6 \mathrm{vol} \%$ & 1350 & 44 & 0.58 & 38.4 & 0.31 & 0.122 & 0.034 \\
$2.5 \mathrm{vol} \%$ & 1260 & 27 & 0.27 & 11.3 & 0.25 & 1.54 \\
\hline
\end{tabular}

The concentration of nitric acid increased from 1.3 to $18.6 \mu \mathrm{g} / \mathrm{m}^{3}$ when the concentration of $\mathrm{O}_{2}$ was increased from $225 \mathrm{ppm}$ to 4.1 vol.\% (Table 5). $\mathrm{HNO}_{3}$ was probably formed from oxidation of $\mathrm{NH}_{3}, \mathrm{NO}$ and $\mathrm{NO}_{2}$ in the syngas. However, the concentration of particulate nitrates did not increase substantially. This is probably due to the fact that potassium nitrate and sodium nitrate decompose at 400 and $380{ }^{\circ} \mathrm{C}$, respectively, which is well below the operating temperatures of the thermochemical conversion system [27].

Although nitrogen in the wood feedstock is in much higher concentration than sulfur (Table 2), the concentration of sulfates in the particulates was found to be several times greater than nitrates (Table 5). These data are consistent with previous studies [28], which reported that the pyrolysis of wood in the presence of oxygen forms particles that primarily comprised potassium and sulfate as a result of the following reaction.

$2 \mathrm{KOH}+\mathrm{SO}_{2}+1 / 2 \mathrm{O}_{2} \rightarrow \mathrm{K}_{2} \mathrm{SO}_{4}+\mathrm{H}_{2} \mathrm{O}$

Table 5 also summarizes the effect of $\mathrm{O}_{2}$ concentrations on the ratios of particulate to gas-phase sulfur and nitrogen species in the syngas. It is shown that increasing $\mathrm{O}_{2}$ in the thermochemical conversion process did not have a significant effect on the ratio of these particulate to gas-phase species.

Table 6 summarizes the effect of $\mathrm{O}_{2}$ on the concentrations of benzene, toluene, xylenes and selected polynuclear aromatic hydrocarbon (PAH) compounds in the syngas. There was a decrease in the concentration of benzene by about six times when $\mathrm{O}_{2}$ was increased from $225 \mathrm{ppm}$ to
1.0 vol.\%. The benzene concentration then stayed relatively constant from 1.0 to $2.5 \mathrm{vol} \% \mathrm{O}_{2}$. In contrast, the toluene and xylene concentrations increased when the $\mathrm{O}_{2}$ was increased from $225 \mathrm{ppm}$ to $1.0 \mathrm{vol} . \%$ but then stayed relatively constant from 1.0 to $2.5 \mathrm{vol} . \% . \mathrm{O}_{2}$.

The concentrations of the PAH compounds (naphthalene, methyl-naphthalene, fluorene, and acenapthene) also increased by several times as $\mathrm{O}_{2}$ increased from $225 \mathrm{ppm}$ to $2.5 \mathrm{vol} \%$. At temperatures above $100{ }^{\circ} \mathrm{C}$, these four PAH compounds are present entirely in the gasphase, whereas at $25^{\circ} \mathrm{C}$ (the syngas sampling temperature) they are distributed between the particulate and gas-phase [15-17]. Therefore, these specific PAH compounds will not act as poisons in catalytic reactions, or cause fouling of engines and turbines, in applications where operating temperatures exceed $200{ }^{\circ} \mathrm{C}$.

Table 7 summarizes the effect of $\mathrm{O}_{2}$ on the concentrations of oxygenated PAH compounds in syngas. As expected, an increase of $\mathrm{O}_{2}$ in the integrated solid and gasphase steam reforming processes significantly increased the concentration of these oxygenated PAH. High concentrations of these oxygenated PAH have also been reported in particulates generated from diesel engines [17]. Since diesel engines operate with excess $\mathrm{O}_{2}$, their chemistry of formation is expected to be comparable to this thermochemical process.

Table 8 summarizes the effect of $\mathrm{O}_{2}$ on the concentrations of formaldehyde, acetaldehyde and benzaldehyde in the syngas. An increase of $\mathrm{O}_{2}$ in the thermochemical process reduced the concentrations of these three aldehydes by 
Table 7 Effect of oxygen input on concentrations of oxygenated-PAH derivatives in syngas generated from the thermochemical conversion of wood

\begin{tabular}{lllll}
\hline Oxygen input & \multicolumn{2}{l}{ Syngas particulate-phase contaminants $\left(\mu \mathrm{g} / \mathrm{m}^{3}\right)$} \\
\cline { 2 - 5 } & Hydroxy-naphthalenes & Dihydroxy-naphthalenes & Dihydro-inden-2-ones & Benzo-pyranones \\
\hline $225 \mathrm{ppm}$ & 0.0 & 0.0 & 0.0 & 0.0 \\
$1.0 \mathrm{vol} . \%$ & 288 & 97 & 32 & 105 \\
$1.6 \mathrm{vol} \%$ & 930 & 311 & 90 & 131 \\
$2.5 \mathrm{vol} \%$ & 732 & 244 & 83 & 195 \\
\hline
\end{tabular}

Table 8 Effect of oxygen input on concentrations of gas-phase aldehydes in syngas generated from the thermochemical conversion of wood

\begin{tabular}{llll}
\hline \multirow{2}{*}{ Oxygen input } & \multicolumn{3}{l}{ Syngas gas-phase contaminants $(\mathrm{ppb})$} \\
\cline { 2 - 4 } & Formaldehyde & Acetaldehyde & Benzaldehyde \\
\hline $225 \mathrm{ppm}$ & 2.1 & 365 & 9.3 \\
$1.0 \mathrm{vol} \%$ & 1.0 & 47.5 & 0.6 \\
$1.6 \mathrm{vol} \%$ & 0.7 & 109 & 3.7 \\
$2.5 \mathrm{vol} \%$ & 1.4 & 199 & 3.5 \\
\hline
\end{tabular}

nearly two times. This is not surprising since these aldehydes are in a partially oxidized chemical state, and further oxidation will result in the formation of formic acid, acetic acid and benzoic acid.

Table 9 summarizes the effect of $\mathrm{O}_{2}$ on the concentrations of particulate calcium, silicon, potassium and sodium in the syngas. It was found that an increase of $\mathrm{O}_{2}$ in the integrated solid and gas-phase steam reforming processes results in a significant increase of particulate calcium, and potassium species in the syngas, but not sodium species. This is probably because calcium and potassium are 10 and 6 times more abundant than sodium in the wood feedstock (Table 2).

The data in Table 10 demonstrate that an increase of $\mathrm{O}_{2}$ from 1.6 to 2.5 vol.\% in the integrated solid and gas-phase steam reforming processes significantly reduced the concentrations of four easily oxidized, unsaturated gas-phase hydrocarbons: 1,3-butadiene, acetylene, propene, and ethene. The decrease in abundance (due to oxidation) of these hydrocarbons was highest for 1,3-butadiene (the most reactive species) and lowest for ethene, which is in agreement with previously reported data from laboratory oxidation studies [24-26].

Table 11 summarizes the average concentrations of contaminants from the plant operating over a period of 3 days at an average $\mathrm{O}_{2}$ system concentration of $225 \mathrm{ppm}$. These data were obtained from syngas sampled after the final polishing (purification) step. As shown here, the average concentrations of key contaminants in the syngas
Table 9 Effect of oxygen input on concentrations of elemental species in syngas particulates generated from the thermochemical conversion of wood

\begin{tabular}{lllll}
\hline \multirow{2}{*}{ Oxygen input } & \multicolumn{4}{l}{ Syngas particulate contaminants $\left(\mu \mathrm{g} / \mathrm{m}^{3}\right)$} \\
\cline { 2 - 5 } & Calcium & Silicon & Potassium & Sodium \\
\hline $225 \mathrm{ppm}$ & 0.0 & 1.6 & 0.3 & 23 \\
$1.0 \mathrm{vol} . \%$ & 1.4 & 1.3 & 9.0 & - \\
$1.6 \mathrm{vol} \%$ & 6.4 & 9.8 & 27 & 4 \\
$2.5 \mathrm{vol} \%$ & 32 & 8.6 & 128 & 15 \\
4.1 vol.\% & 86 & 91 & 127 & 20 \\
\hline
\end{tabular}

were very low when the $\mathrm{O}_{2}$ input concentrations in the system were maintained below $500 \mathrm{ppm}$.

Table 12 summarizes the distribution of plant carbon inputs and outputs generated from the conversion of $1000 \mathrm{~kg}$ of biomass carbon to products and the carbon mass balances for the TCC and LFP systems as well as the total integrated plant. The primary products from the TCC conversion of wood include syngas, biochar and organic contaminants removed from the syngas by the water scrubber. The total carbon quantified in these products represented $97.7 \%$ of the carbon input into the TCC.

\section{Discussion}

It has been demonstrated that the presence of $\mathrm{O}_{2}$ during thermochemical processes has a significant effect on the formation of syngas contaminants. The concentration of particulate organic carbon compounds increased from 3.3 to $122 \mathrm{mg} / \mathrm{m}^{3}$ and particulate elemental carbon increased from 0.6 to $98 \mathrm{mg} / \mathrm{m}^{3}$ when $\mathrm{O}_{2}$ was increased from $225 \mathrm{ppm}$ to $4.1 \mathrm{vol} . \%$. It is proposed that free-radical oxidation of hydrocarbon gases during the thermochemical process is a primary chemical mechanism for the formation of high molecular weight polynuclear aromatic hydrocarbons, oxygenated hydrocarbons and polymeric materials, which are commonly referred to as organic particulate contaminants. These chemical mechanisms were confirmed 
Table 10 Effect of increased oxygen concentration (1.6-2.5 vol.\%) on the reduction of unsaturated, gas-phase hydrocarbons relative to ethane in syngas generated from the thermochemical conversion of wood

\begin{tabular}{llccc}
\hline Syngas component & \multicolumn{4}{l}{ Decrease in syngas constituents relative to concentration of ethane } \\
\cline { 2 - 4 } & 1,3 -Butadiene & Acetylene & Propene & Ethene \\
\hline Relative concentration decrease with increased oxygen & 9.3 times & 5.2 times & 4.5 times & 3.4 times \\
\hline
\end{tabular}

Table 11 Average concentrations of contaminants (after unit operation \#4b) from the pilot IBR plant operating with less than 500 ppm oxygen input compared to maximum recommended contaminant levels for catalytic conversion of syngas to liquid fuels

\begin{tabular}{lll}
\hline Catalyst contaminants & $\begin{array}{l}\text { 3-Day average syngas contaminant } \\
\text { concentrations }\end{array}$ & $\begin{array}{l}\text { Maximum recommended contaminant } \\
\text { levels }\end{array}$ \\
\hline $\begin{array}{l}\text { Hydrogen sulfide }\left(\mathrm{H}_{2} \mathrm{~S}\right) \text { and carbonyl } \\
\text { sulfide }(\mathrm{COS})\end{array}$ & $0.1 \mathrm{ppb}$ & $<20 \mathrm{ppb}$ \\
Sulfur dioxide $\left(\mathrm{SO}_{2}\right)$ & $0.7 \mathrm{ppb}$ & $<20 \mathrm{ppb}$ \\
Oxygen $\left(\mathrm{O}_{2}\right)$ & $225 \mathrm{ppm}$ & $<500 \mathrm{ppm}$ \\
Ammonia $\left(\mathrm{NH}_{3}\right)$ & $53 \mathrm{ppb}$ & $<75 \mathrm{ppb}$ \\
Hydrogen chloride $(\mathrm{HCl})$ & $<0.2 \mathrm{ppb}$ & $<35 \mathrm{ppb}$ \\
Nitric acid $\left(\mathrm{HNO}_{3}\right)$ & $5 \mathrm{ppb}$ & $<50 \mathrm{ppb}$ \\
Total particulate matter $(\mathrm{PM})$ & $25 \mu \mathrm{gg} / \mathrm{m}^{3}$ & $<500 \mu \mathrm{gg} / \mathrm{m}^{3}$ \\
\hline
\end{tabular}

Table 12 Distribution of plant carbon inputs and outputs generated from the conversion of $1,000 \mathrm{~kg}$ of biomass carbon to carbon containing products

\begin{tabular}{lc}
\hline Components & $\mathrm{kg}$ of $\mathrm{C}$ in TCC products \\
\hline $\mathrm{H}_{2}$ & 0.0 \\
$\mathrm{CO}$ & 417.0 \\
$\mathrm{CH}_{4}$ & 285.0 \\
$\mathrm{CO}_{2}$ & 122.6 \\
$\mathrm{C}_{2}-\mathrm{C}_{5} \mathrm{HCs}$ & 4.2 \\
Biochar & 135.5 \\
$\mathrm{C}$ in scrubber water & 13.0 \\
Total kg carbon & 977.3 \\
\hline
\end{tabular}

by studying the concentrations of selected oxygenated hydrocarbons formed from this plant.

The biomass thermochemical conversion processes described herein use heat, pressure and steam (in the absence of air). These processes encompass a complex set of reactions involving the formation, propagation and termination of radical species for which there are numerous free-radical pathways. It is well known that hydrogen $\left(\mathrm{H}^{*}\right)$, hydroxyl $\left(\mathrm{OH}^{*}\right)$, oxy $\left(\mathrm{O}^{*}\right)$ and hydroperoxy $\left(\mathrm{OOH}^{*}\right)$ radicals are important reactive intermediates in these hightemperature oxidation processes [24-26] as shown by reactions (1)-(5). In addition, reaction of the hydroxy radical with methane is the predominant formation process for methyl $\left(\mathrm{CH}_{3}^{*}\right)$ radicals, as shown by reaction (6).

$\mathrm{H}_{2} \rightarrow 2 \mathrm{H}^{*}$

$\mathrm{H}_{2}+\mathrm{O}_{2} \rightarrow 2 \mathrm{OH}^{*}$

$\mathrm{H}^{*}+\mathrm{O}_{2} \rightarrow \mathrm{O}^{*}+{ }^{*} \mathrm{OH}$

$\mathrm{O}^{*}+\mathrm{H}_{2} \rightarrow \mathrm{OH}^{*}+\mathrm{H}^{*}$

$\mathrm{H}^{*}+\mathrm{O}_{2} \rightarrow \mathrm{OOH}^{*}$

$\mathrm{CH}_{4}+{ }^{*} \mathrm{OH} \rightarrow \mathrm{CH}_{3}^{*}+\mathrm{H}_{2} \mathrm{O}$

Table 3 shows that the $\mathrm{H}_{2}$ concentration decreased from 49 to 37 vol.\% when the $\mathrm{O}_{2}$ input was increased from $225 \mathrm{ppm}$ to $4.1 \mathrm{vol} \%$, which we propose is the result of reactions (2), (3) and (5). The $\mathrm{CH}_{4}$ concentration decreased from 12 to 9 vol. $\%$ as $\mathrm{O}_{2}$ increased from $225 \mathrm{ppm}$ to 4.1 vol.\%, as an outcome of reaction \#6.

The abundant primary radical $\left(^{*}\right)$ species $\mathrm{H}^{*}, \mathrm{OH}^{*}, \mathrm{O}^{*}$, $\mathrm{CH}_{3}{ }^{*}$ and $\mathrm{OOH}^{*}$ react with the myriad of organic compounds in the syngas at varying rates and high reforming temperatures. For example, the abundant hydrogen radical reacts rapidly with benzene to form a benzyl radical as shown by reaction (7). Since benzene is a major constituent in the syngas (Table 6), this is likely the major source of $\mathrm{C}_{6} \mathrm{H}_{5}{ }^{*}$.

$\mathrm{C}_{6} \mathrm{H}_{6}+\mathrm{H}^{*} \rightleftarrows \mathrm{C}_{6} \mathrm{H}_{5}^{*}+\mathrm{H}_{2}$

These benzyl radicals react quickly with hydroxy radicals to form phenol (reaction 8). Phenol may also be 
formed by the reaction of two hydroxy radicals with benzene (reaction 9).

$$
\begin{aligned}
& \mathrm{C}_{6} \mathrm{H}_{5}^{*}+\mathrm{OH}^{*} \rightleftarrows \mathrm{C}_{6} \mathrm{H}_{5} \mathrm{OH} \\
& \mathrm{C}_{6} \mathrm{H}_{6}+2 \mathrm{OH}^{*} \rightarrow \mathrm{C}_{6} \mathrm{H}_{5} \mathrm{OH}+\mathrm{H}_{2} \mathrm{O}
\end{aligned}
$$

Since reaction \#8 is a reversible process, the addition of higher concentrations of $\mathrm{OH}^{*}$ and their subsequent reaction with $\mathrm{C}_{6} \mathrm{H}_{5}{ }^{*}$ helps drive reaction (8) to the right. The data in Table 6 help validate these reaction paths since benzene is reduced from $5845 \mathrm{ppm}$ when $\mathrm{O}_{2}$ is $225 \mathrm{ppm}$ to an average of $1150 \pm 200 \mathrm{ppm}$ when $1.0-2.5 \mathrm{vol} . \%$ of $\mathrm{O}_{2}$ is present.

The benzyl radicals may also react with $\mathrm{CH}_{3}{ }^{*}$ to produce toluene (reaction 10). As a result, toluene increased from $3.9 \mathrm{ppm}$ at $225 \mathrm{ppm}$ of $\mathrm{O}_{2}$ to an average of $32 \pm 10 \mathrm{ppm}$ when 1.0-4.1 vol.\% of $\mathrm{O}_{2}$ is present, which further supports this reaction path.

$\mathrm{C}_{6} \mathrm{H}_{5}^{*}+\mathrm{CH}_{3}^{*} \rightarrow \mathrm{C}_{7} \mathrm{H}_{8}$

In a similar fashion, the hydroxy radicals react with other aromatics, polycyclic aromatics, alkanes, and alkenes to form hydroxy and di-hydroxy derivatives. As a result, thermochemical processes that use oxygen or oxygen/ steam mixtures produce organic particulate contaminants that contain high concentrations of phenolics such as phenol, cresol, xylenols and ethyl-phenols [23].

Table 7 summarizes the concentrations of the hydroxy and di-hydroxy derivatives of naphthalene. As expected, the concentrations of these compounds increased rapidly as the concentration of oxygen in the process was increased.

Higher molecular weight PAH may be formed from the reaction of $\mathrm{C}_{6} \mathrm{H}_{5}{ }^{*}$ with lower molecular weight PAH. For example, pyrene $\left(\mathrm{C}_{16} \mathrm{H}_{10}\right)$ can be formed from naphthalene $\left(\mathrm{C}_{10} \mathrm{H}_{8}\right)$ and $\mathrm{C}_{6} \mathrm{H}_{5}{ }^{*}$ as shown by Eq. (8) and benzo (a) pyrene $\left(\mathrm{C}_{20} \mathrm{H}_{12}\right)$ from pyrene $\left(\mathrm{C}_{16} \mathrm{H}_{10}\right)$ and $\mathrm{C}_{6} \mathrm{H}_{5}{ }^{*}$ as given by Eq. (9) [20].

$$
\begin{aligned}
& \mathrm{C}_{6} \mathrm{H}_{5}^{*}+\mathrm{C}_{10} \mathrm{H}_{8} \rightarrow \mathrm{C}_{16} \mathrm{H}_{10}+\mathrm{H}^{*}+\mathrm{H}_{2} \\
& \mathrm{C}_{6} \mathrm{H}_{5}^{*}+\mathrm{C}_{16} \mathrm{H}_{10} \rightarrow \mathrm{C}_{20} \mathrm{H}_{12}+\mathrm{C}_{2} \mathrm{H}_{3}^{*}
\end{aligned}
$$

The importance of these oxidation processes was further confirmed by studying the decrease of other easily oxidized hydrocarbons. For example, the concentrations of the highly reactive alkenes and alkyl dienes; 1,3-butadiene, acetylene, propene and ethene decreased by $9.3,5.2,4.5$ and 3.4 times, respectively, when the $\mathrm{O}_{2}$ concentration was increased from 1.6 to 2.5 vol. $\%$.

The hydroxy radicals $\left(\mathrm{OH}^{*}\right)$ and hydroperoxy radicals $\left(\mathrm{HO}_{2}{ }^{*}\right)$ also react with $\mathrm{CO}$ according to reactions 10 and 11.

$\mathrm{CO}+\mathrm{OH}^{*} \rightarrow \mathrm{CO}_{2}+\mathrm{H}^{*}$

$\mathrm{CO}+\mathrm{OOH}^{*} \rightarrow \mathrm{CO}_{2}+\mathrm{OH}^{*}$

These reactions are substantiated by the data in Table 3 which show that the $\mathrm{CO}$ concentration dropped from 23 to 17 vol. $\%$ as $\mathrm{O}_{2}$ increased from $225 \mathrm{ppm}$ to $4.1 \mathrm{vol} . \%$, with a corresponding increase in $\mathrm{CO}_{2}$ (17-23 vol.\%).

\section{Conclusions}

It has been demonstrated that the thermochemical process described in this paper, when operated at a nominal oxygen concentration of $225 \mathrm{ppm}$, produces much lower concentrations $\left(\sim 3.9 \mathrm{mg} / \mathrm{m}^{3}\right.$ ) (sum of organic and elemental carbon in Table 4) of particulate contaminants than the traditional thermochemical conversion systems described in the literature.

For example, the National Renewable Energy Laboratory (NREL) compared the concentrations of particulate contaminants in syngas from several types of thermochemical conversion systems that employ air or $\mathrm{O}_{2}$ [8]. It was concluded that average total particulate contaminant concentrations are approximately 1000, 10,000, and $100,000 \mathrm{mg} / \mathrm{m}^{3}$ for typical fluidized bed, downdraft, and updraft systems, respectively (Table 13). In a more recent study, Stark et al. measured $2000-50,000 \mathrm{mg} / \mathrm{m}^{3}$ of organic particulate contaminants from their air-blown, fluidized bed biomass gasification system [18].

In addition to tar formation, the presence of oxygen in the thermochemical process has other adverse effects on the efficiency of the integrated biorefinery when oxygen is increased from $225 \mathrm{ppm}$ to $4.1 \mathrm{vol}$. \% (Table 3 ) as follows:

1. A reduction in $[\mathrm{CO}]$ and $\left[\mathrm{H}_{2}\right]$ of 26 and $24 \%$, respectively. Since $\mathrm{CO}$ and $\mathrm{H}_{2}$ are the primary chemical species that produce fuels and chemicals, the production efficiency of these products will be reduced by about $25 \%$.

Table 13 Concentrations of particulate components in syngas generated from the pilot IBR plant compared to other types of thermochemical systems (before syngas purification processes)

Total particulate contaminant concentrations $\left(\mathrm{mg} / \mathrm{m}^{3}\right)$

\begin{tabular}{llll}
\hline $\begin{array}{l}\text { This study } \\
\begin{array}{l}\text {-stage steam reforming TCC system } \\
\left(225 \mathrm{ppm} \% \mathrm{O}_{2} \text { input }\right)\end{array}\end{array}$ & $\begin{array}{l}\text { Typical fluidized bed system } \\
\text { (with air input) }\end{array}$ & $\begin{array}{l}\text { Typical downdraft system } \\
\text { (with air input) }\end{array}$ & $\begin{array}{l}\text { Typical updraft system (with } \\
\text { air input) }\end{array}$ \\
\hline 3.9 & 1000 & 10,000 & 100,000 \\
\hline
\end{tabular}


2. An increase in $\left[\mathrm{CO}_{2}\right]$ of $26 \%$ and an increase in $\left[\mathrm{N}_{2}\right]$ from $<0.20$ vol.\% to 15.3 vol. \%. Since $\mathrm{CO}_{2}$ and $\mathrm{N}_{2}$ are diluents in the catalytic reaction, this increase from 29 vol.\% to $47 \mathrm{vol} . \%$, requires that the volume of the catalytic reactors will need to be increased by about $38 \%$ at significant additional cost.

This effect of $\mathrm{O}_{2}$ on $\mathrm{H}_{2} / \mathrm{CO}$ ratios has also been studied by Karimipour et al. [29], who varied $\mathrm{O}_{2} /$ steam ratios in a fluidized bed gasifier. They measured $\mathrm{H}_{2} / \mathrm{CO}$ ratios of 0.81 , 1.02 and 1.27 at $\mathrm{O}_{2}$ /steam ratios of 2.0, 1.0 and 0.75 , which demonstrates that increasing levels of $\mathrm{O}_{2}$ reduce the concentrations of $\mathrm{H}_{2}$ and $\mathrm{CO}$ during thermochemical conversion processes.

Another potential problem with the presence of $\mathrm{O}_{2}$ in thermochemical processes is the effect of residual oxygen in the syngas on the catalysts used for the production of fuels and chemicals. Since these catalysts need to be kept in a reduced state for the efficient production of fuels and chemicals from $[\mathrm{CO}]$ and $\left[\mathrm{H}_{2}\right]$, any residual oxygen in the syngas will quickly re-oxidize these reduced catalysts to their non-reactive, oxidation state, resulting in reduced fuel production efficiency and potential damage to the catalysts.

The thermochemical process shown in Fig. 1 was upgraded from about 4.5-22 metric ton/day capacity during 2011 and was tested for a total of $1170 \mathrm{~h}$ on wood and rice hull feedstocks during $5 / 2012$ to $9 / 2013$. It was found that fuel productivity increased slightly from 53.0 gallons/ $1000 \mathrm{lbs}$. to 56.6 gallons $/ 1000 \mathrm{lbs}$. of biomass carbon during this test period, which confirmed that oxygen and the other syngas contaminants listed in Table 1 were kept at low levels and had no discernible effect on the direct fuel production catalyst.

Acknowledgments Funding support is acknowledged from the US Department of Energy (DOE) award for the DOE Grant \#DE-FC3603GO13071 (Gridley Biofuels Project). Operation of the thermochemical system was provided by Doug Struble and Roger Jorgenson of Red Lion Bio-Energy. Sampling of the thermochemical system was carried out by Doug Struble along with Curtis Robbins and Xiaoliang Wang of DRI. The support of Alex Johnson of Red Lion Bioenergy in helping make this project a reality is greatly appreciated. We also acknowledge John Watson and Judith Chow of DRI for development of the dilution sampling system. Steve Kohl, Mark McDaniel, and Anna Cunningham of DRI conducted all laboratory analyses.

\section{Compliance with ethical standards}

Conflict of interest The author(s) declare that they have no competing interests

Open Access This article is distributed under the terms of the Creative Commons Attribution 4.0 International License (http://crea tivecommons.org/licenses/by/4.0/), which permits unrestricted use, distribution, and reproduction in any medium, provided you give appropriate credit to the original author(s) and the source, provide a link to the Creative Commons license, and indicate if changes were made.

\section{References}

1. U.S. Department of Energy (DOE): Multi-year program plan. DOE Report \#EE-1193, U.S. DOE Bioenergy Technologies Office, Golden (2015)

2. U.S. Department of Energy (DOE): Energy efficiency and renewable energy programs. U.S. DOE Bioenergy Technologies Office, Golden (2011)

3. U.S. Department of Energy (DOE): Thermochemical conversion. DOE Report \#EE-0949, U.S. DOE Bioenergy Technologies Office, Golden (2013)

4. Perlack, RD, Wright, LL, Turhollow, AF, Graham, RL, Stokes, BJ, Erbach, DC: Biomass as feedstock for a bioenergy and bioproducts industry: the technical feasibility of a billion-ton annual supply. Oak Ridge National Laboratory Technical Report \#TM2005/66, Oak Ridge, TN (2005)

5. Perlack, R.D., Stokes, B.J.: U.S. billion-ton update: biomass supply for a bioenergy and bioproducts industry. Oak Ridge National Laboratory Technical Report \#TM-2011/224, Oak Ridge (2011)

6. Kumar, A., Jones, A.A., Hanna, M.A.: Thermochemical biomass gasification-a review of the current status of the technology. Energies 2, 556-581 (2009)

7. Bridgewater, A.V.: Advances in Thermochemical Biomass Conversion. Springer Science and Business Media, Berlin, 1-1734 (2013)

8. Milne, T.A., Evans, R.J., Abatzoglou, N.: Biomass gasifier organic particulate contaminants-their nature, formation, and conversion. National Renewable Energy Laboratory Technical Report TP-570-25357, Golden (1998)

9. European Committee for Standardization: Biomass gasificationTar and particulates in product gases-sampling and analysis. CEN/TS Technical Report \#15439, Brussels (2006)

10. Rabou, L.P.L.M., Zwart, R.W.R., Vreugdenhil, B.J., Bos, L.: Tar in biomass producer gas. The Energy Research Centre of the Netherlands (ECN). Energy Fuels 23, 6189-6198 (2009)

11. Van Passen, S.V.B., Kiel, J.H.A.: Tar formation in fluidized-bed gasification: impact of gasifier operating conditions. Agency for Research in Sustainable Energy Report \#ECN-C-04-013, Petten (2004)

12. Dry, M.E.: Fischer-Tropsch technology: studies in surface science and catalysis. 152, Stenberg, AP, Dry, ME, Ed. Elsevier, Amsterdam, pp. 533-600 (2004)

13. Schuetzle, D., Tamblyn, G., Caldwell, M., Hanbury, O., Schuetzle, R., Rodriquez, R., Johnson, A., Deichert, F., Jorgensen, R., Struble, D.: Demonstration of a pilot integrated biorefinery for the efficient conversion of biomass to diesel fuel, DOE Technical Report \#DE-EE0002876, pp. 1-256. U.S. DOE Bioenergy Technologies Office, Golden (2015)

14. Schuetzle, D., Caldwell, M., Ganz, D., Hurley, R., Tamblyn, G., Tornatore, G., Jacobson, A.: An Assessment of Biomass Conversion Technologies and Recommendations in Support of the Deployment of a 450 ton/day Integrated Biofuels and Energy Production (IBEP) Plant for the Generation of Ethanol, Electricity and Heat from Rice Harvest Waste and other Agriculture Biomass Resources in Gridley, California. Department of Energy, Golden. Report \#DE-FC36-03G013071, 1-138 (2007)

15. Hoekman, S.K., Robbins, C., Wang, X., Zielinska, B., Schuetzle, D., Schuetzle, R.: Characterization of trace contaminants in syngas from the thermochemical conversion of biomass. Biomass Conv. Bioref. 3, 113-126 (2013)

16. Wang, X., Robbins, C., Hoekman, S.K., Chow, J.C., Watson, J.C., Schuetzle, D.: Dilution sampling and analysis of particulate matter in biomass derived syngas. Front. Environ. Sci. Eng. China 5, 320-331 (2011) 
17. Schuetzle, D.: Sampling of vehicle emissions for chemical analysis and biological testing. Environ. Health Perspect. 47, 53-63 (1983)

18. Stark, A.K., Bates, R.B., Zhao, Z., Ghoniem, A.F.: Prediction and validation of major gas and tar species from a reactor. Energy Fuels 29, 2437-2452 (2015)

19. Ranzi, E., Cuoci, A., Faravelli, T., Frassoldati, A., Migliavacca, G., Pierucci, S., Sommariva, S.: Chemical kinetics of biomass pyrolysis. Energy Fuels 22, 4292-4300 (2008)

20. McGrath, T., Sharma, R., Hajaligol, M.: An experimental investigation into the formation of polycyclic-aromatic hydrocarbons (PAH) from pyrolysis of biomass materials. Fuel 80, 1787-1797 (2001)

21. Bauschlicher, C.W., Ricca, A., Rosi, M.: Mechanisms for the growth of polycyclic aromatic hydrocarbon (PAH) cations. Chem. Phys. Lett. 355, 159-163 (2002)

22. Atri, G., Baldwin, R., Jackson, D., Walker, R.: The reaction of $\mathrm{OH}$ radicals and $\mathrm{HO}_{2}$ radicals with carbon monoxide. Combust. Flame 30, 1-12 (1977)

23. Gil, J., Aznar, M.P., Caballero, M.A., Frances, E., Corella, J.: Biomass gasification in fluidized bed at pilot scale with steamoxygen mixtures-product distribution for very different operating conditions. Energy Fuels. 11, 1109-1118 (1997)

24. Atkinson, R.: Kinetics and mechanisms of the gas-phase reactions of the hydroxyl radical with organic compounds. J. Phys. Chem. Ref. Data, Monograph 1. National Institute of Standards and Technology, Bethesda (1989)

25. Hendry, D.G., Mayo, F.R., Schuetzle, D.: Rapid build-up of pyrophoric polymers from 1,3-butadiene and ethylene. Can. J. Chem. Eng. 62, 367-373 (1984)

26. Denisov, E.T., Afanasev, I.B.: Oxidation and Antioxidants in Organic Chemistry and Biology. CRC Press, New York, 1-981 (2005)

27. Gordon, S., Campbell, C.: Differential thermal analysis of inorganic compounds. Anal. Chem. 27, 1102-1109 (1955)

28. Sippula, O., Hokkinen, J., Puustinen, H., Yli-Pirila, P., Jokiniemi, J.: Particle emissions from small wood-fired district heating units. Energy Fuels 23, 2974-2982 (2009)

29. Karimipour, S., Gerspacher, R., Gupta, R., Spiteri, R.J.: Study of factors affecting syngas quality and their interactions in fluidized bed gasification of lignite coal. Fuel 103, 308-320 (2013)

Dennis Schuetzle is Chief Technology Officer for Greyrock Energy (http://www.greyrock.com) and President of the Renewable Energy Institute International (http://www.reiinternational.org). $\mathrm{He}$ has 41 years of experience in managing scientific and engineering research, product development and manufacturing, renewable energy and fuel production processes, and environmental science and technology programs in collaboration with organizations in North America, Asia, Europe, South America, Russia and South Africa. Prior to his positions with Greyrock and REII, he was Director/Vice President of International Research and Technology (IR\&T) for Ford Motor Company from 1994-2003. He has published 113 scientific and engineering papers, edited four books, contributed to 76 technical books and received 12 patents. He is the recipient of 11 international awards including five RD100 awards for the successful commercial deployment of new technologies into the global marketplace. Dr. Schuetzle obtained Ph.D.s in Chemistry and Civil and Environmental Engineering from the University of Washington, a MS degree from Stanford in Chemical Physics/Computer Science, and a BS degree in Chemistry from California State University-San Jose.

Robert Schuetzle is the President of Greyrock Energy (http://www. greyrock.com). His company is currently managing the deployment of commercial plants in the US and Canada for the conversion of natural gas and natural gas liquids to synthetic diesel fuel. He recently completed DOE demonstration projects for the conversion of biomass to drop-in fuels and solar reforming of carbon dioxide to produce diesel fuel. Prior to this leadership position with Greyrock, he was as a Principal with EMC Corporation and also a Consultant for Accenture in which he managed strategy and technology projects for clients in the Americas, Europe and Asia-Pacific. He was awarded EMC's prestigious award for his efforts related to new market development. During 1998-2000 was CEO of Digitella Technology in which he developed and patented the key technologies that have made it possible for cell phones and other devices to acquire, store and transmit digital media. Mr. Schuetzle obtained his B.S. in Mechanical Engineering from the University of Michigan and Computer Engineering Specialty from the University of New South Wales, Australia. He is a frequent industry speaker, has published several technical papers on renewable energy and renewable fuels, and holds seven patents.

S. Kent Hoekman is a Research Professor at the Desert Research Institute (DRI) in Reno, Nevada (http://www.dri.edu.). His research interests include development of renewable energy systems, conversion of biomass to biofuels, environmental impacts of fuels and energy systems, and air quality impacts of vehicle emissions. He has 35 years of experience in defining, conducting, and managing scientific research in these areas. Prior to joining DRI, Dr. Hoekman spent 21 years at Chevron, where he focused on technical and regulatory issues related to transportation fuels, mobile source emissions controls, vehicle technology, and urban air quality. He obtained a Ph.D. in Organic Chemistry from Iowa State University, and a B.S. in Chemistry from Calvin College.

Barbara Zielinska is an Emeritus Research Professor at the Desert Research Institute (DRI). Her research interests include sampling and analysis of trace organic species present in the atmosphere (both gasphase and particle-phase), development of analytical methods to characterize primary and secondary organic aerosols, kinetics and products of gas-phase reactions of organics, and characterization of organic emissions from mobile and stationary sources. For 25 years, Dr. Zielinska served as Director of DRI's Organic Analytical Laboratory (OAL). Prior to joining DRI, she worked at the Statewide Air Pollution Research Center at U.C. Riverside. She obtained a Ph.D. in Chemistry from the Polish Academy of Sciences and a M.Sc. in Chemistry from the Technical University of Lodz, Poland. 